Urban Design and Planning Volume 169 Issue DP5

Matching a community assessment tool to the requirements of practice AlWaer and Kirk

\title{
Matching a community assessment tool to the requirements of practice
}

Husam AlWaer BArch, PhD, BREEAM AP, AoU, SuBETool Founder Senior Lecturer in Sustainable Urban Design and Evaluation, The University of Dundee, School of the Environment, Architecture + Planning, Dundee, UK
R. David Kirk MA, MPhil., DMS

Research Fellow, The University of Dundee, School of the Environment, Architecture + Planning, Dundee, UK

Over the last two decades, performance-based metrics have been applied in master planning as a means to estimate the impacts of large-scale development on the local and global environment. Community sustainability assessment has developed to provide a practical method for assessing the performance of a spatial master plan against an array of sustainability indicators. This paper considers the adequacy of such a tool to provide reliable information when and as required for decision-making in the planning process. It reviews Breeam (building research establishment environmental assessment method) Communities 2012 specifically examining whether this tool provides an analysis which is strategic, comprehensive and integrated. Breeam 2012 is found to be adequately comprehensive in the current operational context of the British planning system. The sustainability assessment model can usefully inform decision-making at the strategic 'stage gates' of master planning. However, the analytical methodology of the assessment model is inherently fractional. This complicates how a 'balanced' evaluation of the relative importance of sustainability issues is reached and agreed. It is suggested that a project culture of trans-disciplinary dialogue and explorative learning is required to promote the understanding and use of sustainability assessment practice in master planning.

\section{Introduction}

In the closing decades of the twentieth century, concern about the adverse implications of climate change and of environmental degradation stimulated scientific interest in developing analytical methods for assessing the impacts of development proposals within critical environmental sectors. The practice of environmental impact assessment that measure the impacts on environmental sustainability of major developments became a regulatory requirement by the force of the European Union's Environmental Impact Assessment (EIA) Directive (Directive 85/337/EEC) (EC, 2015) in 1985. The Strategic Environmental Assessment (SEA) Directive followed European Directive (2001/ 42/EC) (EC, 2001). This requires authorities that hold responsibilities for making policies, plans and programmes to integrate environmental consideration into the preparation and adoption of plans and programmes with a view to provide for sustainable development. In the UK this is applied to the town and country planning system that requires planning authorities to make SEA a parallel part of the process of preparing statutory framework spatial plans, which provide the basis for determining the future development consent of projects. The Planning and Compulsory Purchase Act 2004 (2004) requires planning authorities to carry out the process requirements of SEA in the preparation of such statutory local development plans.
The appreciation of the scope of sustainable development expands beyond concern with environmental impacts and embraces the importance of the social and economic dimensions of sustainability. Resolution 42/187 of the UN General Assembly (UN, 1987) defined sustainable development as the meeting of the needs of the present without compromising the ability of future generations to meet their own needs. Its implications require that the social and economic effects of development as well as environmental consequences are considered. This understanding of sustainable development underpins the UK government's sustainable development strategy set out in the 2005 policy document 'Securing the Future - delivering a UK sustainable development strategy' (HM Government, 2005). The five guiding principles require: living within environmental limits; ensuring a strong, healthy and just society; achieving a sustainable economy; promoting good governance; and using sound science responsibly.

As Karol and Brunner (2009: p. 613) identified 'the only way of establishing whether urban developments are becoming less environmentally, socially and financially damaging is to measure their performance and provide comparative analysis'. Although retrospective evaluation of outcomes and consequences may be made, sustainability assessment is concerned 
with identifying the potential impacts and consequences of proposed development. It is future oriented and seeks to reduce the uncertainties and unknowns about that future. Writing in 1981, Patton defined assessment as follows: 'the systematic collection of information about the activities, characteristics and outcomes of programs, personnel and products for use by specific people to reduce uncertainties, improve effectiveness and make decisions with regard to what those programs, personnel or products are doing and affecting' (Patton, 1981: p. 15).

In the last decade, comprehensive sustainability assessment systems (CSAs) have been developed as tools for consolidating information, measuring from a sustainability perspective the long-term implications of large development plans and projects. A CSA provides a standardised approach to the measurement of the impacts of such plans and projects across a range of social, economic and environmental criteria. The purpose of a CSA is to inform decision-making during the processes of planning, design and appraisal of such projects.

\section{The interest and structure of the paper}

The value of a CSA lies in its function in foreseeing and gauging the implications for sustainability of complex development plans and projects. The interest of this paper lies in examining whether a CSA tool provides an adequate assessment framework that can be used in master planning to better inform decision-making. This requires considering how sustainability assessment fits within the statutory procedural requirements in relation to master planning, and whether the use of the tool provides information that can appropriately inform about the consequences for sustainability of a development project at the stages of the planning process when decisions are made that progressively settle the content and design of the master plan. As a method of making this review, the CSA method deployed in building research establishment environmental assessment method (Breeam) Communities (Breeam Communities, 2012) (Breeam is a product of BRE Global Limited, a third party approvals body and as a part of the BRE Group is owned by the BRE Trust) is appraised in the operational context of master planning within the British development planning system. The review is primarily based by drawing on relevant literature and is informed by the experience of professional sustainability assessors and spatial planners.

Examination is preceded by preparatory descriptions that frame the development context within which sustainability assessment is undertaken. The regulatory system through which applications for permission to develop large urban neighbourhoods are assessed is described. The process of preparing a master plan, the key element by which such development proposals are conceived is then outlined. The generic characteristics of the CSA approach are then outlined. With the procedural context and processes of planning and assessment so described, the adequacy of Breeam to inform decision-making is then considered.

\section{The regulatory planning system and the master-planning process}

Proposals for large-scale and complex development projects are responses to the pressures and opportunities presented by changing conditions. In the UK, as elsewhere, there are considerable pressures for urban development arising from structural change in economy and society. In particular, population increase in many urban centres, and especially within the growing local economies of the southern counties of England, has created a huge demand for more housing and related infrastructure and facilities development (Barker, 2004; Holmans, 2013).

Urban development is subject to a regulatory regime harnessing spatial planning policy to statutory instruments and procedures to guide and control the development of the built environment. In the UK, the statutory planning system serves to mediate between public and private interests in the use of land. With the passing of the Planning and Compulsory Purchase Act (2004), the principles of sustainable development have increased influence in the regulation of urban development. As development proposals require gaining regulatory approval, the scope of development project appraisal has expanded. In the UK, the governmental management of land use and spatial planning system is devolved. The function is developed with regard to the planning statutes, legal systems and spatial jurisdictions of the devolved administrations for Scotland, Wales and Northern Ireland. The planning system for England remains administered through the unitary state. Although there is difference between the planning regimes, there is a common core of principles, focus and procedures which can be said to define the UK planning system.

In England, the revision of national planning policy in the form of the National Planning Policy Framework (Department for Communities and Local Government, 2012) was built on the basis provided by the SEA Directive. Within the regulated planning system, development decisions by the planning authorities are made within a statutory plan-led framework. Delivery of sustainable development is a key objective of such local development plans. Planning authorities are required to prepare these policy frameworks for land use and spatial development in their area to contribute to the achievement of sustainable development. The local development plan provides the basis for decisions by the planning authority on development applications. 
Although the local development plans of the planning authorities allocate land suitable for development, property development in the UK is largely driven by commercial developers. Often where large-scale residential development is proposed, the developers will be high-volume house-building companies. Developers bring forward development applications for land identified in the local plans to seek planning permission from the local planning authorities. Developers assess major development projects, taking into account the market, and technical and financial dimensions of a project. Additionally, developers must assess how their proposals satisfy the principles of sustainable development.

The planning system provides the governance structure, regulatory framework and the procedural processes for the management of development activity. A large development project crosses the interests of multiple statutory bodies each with a specific sphere of regulatory competence. Statutory responsibilities include the protection of the environment, safeguarding against flood risk, pollution control, mediating transport impacts, the provision of public utilities and education, and health and social services. Standards are held by each regulating interest. They are statutory consultees. Development of a large urban area requires collaboration between the developer, the planning authority and the bodies that have regulatory responsibilities for infrastructure and public services, and for protection of the environment. The statutory dimensions of development require that the developer and these regulators reach agreements over how the broad content and shape of the project will meet mandatory requirements before formal approval is given by the planning authority for development activity.

Pre-application consultation by the applying developer with the local community is required and the planning authority will take account of the manner of the consultation and comments arising from the public when deciding on the planning application.

The provision of planning permission that allows for development to be undertaken provides a huge uplift in the value of the affected land. Developers, landowners and their investors stand to secure substantial financial returns when selling newly created property to final users. However, the development of a large new urban neighbourhood imposes extra demands and costs on the public infrastructure and public services. Government views it as reasonable that an appropriate part of the 'planning gain' created by the planning consent is secured to cover the increased public costs and obtain a share for public benefit. Developers provide contributions for infrastructure through several statutory provisions. The Community Infrastructure Levy is a planning charge that came into force in England and Wales in 2010 as a result of the Planning Act 2008 (2008); by way of planning obligations under the provisions of the s106 of the Town and Country Planning Act 1990 (1990) and by s278 highway agreements provided in the Highway Act 1980 (1980). Authorities are expected to negotiate in a reasonable, consistent and transparent manner when establishing the financial contributions required from developers, and with the aim of generating predictable streams of financial contribution for the additional public infrastructure and services attributable as impacts of development (Office of the Deputy Prime Minister, 2005). Such planning obligations provide some material effect to supporting the sustainable development aims of supporting social well-being and justice.

\section{Preparation of the master plan for a large new urban neighbourhood}

The preparation of proposals for the development of a largescale urban neighbourhood has considerable complexity. Attention must be paid to the development plan policy and its strategy of development land allocation, to regulatory requirements and to local demographic change and social needs. This informs the framing of a development brief, which provides the strategic framework of development objectives. The master planning process then proceeds from a base-line analysis of the social, economic and environmental issues. The spatial context of place and connectivity, including the physical issues presented by the site and its capacity for accommodating development, must be surveyed. The reconciliation of the baseline data with the development objectives must be future focused. Consideration of the effects development could have on existing issues, and on problem-solving and mitigation proceed from the analysis. Although the presenting conditions of the market will drive a pragmatic and short-term outlook, for the master-planning approach to provide for sustainable development the developer must hold a long-term vision of outcomes. This preparatory phase of master planning serves to guide the design of the spatial master plan and subsequently the programming of construction phases. Of importance, this process of master-plan preparation provides opportunities for pre-application engagement between the developer, the planning authority and statutory consultees, with private stakeholders and with the local community (Cabe, 2011).

A spatial master plan sets out the physical framework and design principles of the proposed scheme of development. The design identifies the service infrastructure and the architectural and place-scape principles that will guide the layout of the built form and the associated 'green' network (LlewelynDavies, 2007). Nikolas Falk (2011: p. 37) describes the function of master plans in the following terms: 'Framework master plans set out broad urban design and place-making aspirations and principles. They allow scope for interpretation and developments within the framework's parameters'. A master plan establishes the intended long-term spatial character of the 
development. Detailed design of internal 'development parcels' will follow when site phasing is programmed. Their design will be expected to accord with the approved master plan and planning conditions set. Depending on the time scale of master-plan implementation, and some master plans may be programmed to be carried out over 10-20 years, then the scope for variation of planning conditions is a normal practice in response to changing market conditions (AlWaer, 2014).

In summary, the master-plan process has three phases: analysis, developing the design and evaluation/testing the design concept (Cowan, 2002, 2008; Cowan et al., 2010). However, these inter-lock. There will be reconsideration of design factors and solutions throughout the evolution of proposals.

Analysis is concerned with establishing the capability and capacity of a site to be developed as a financially viable project that produces a sustainable long-term urban environment in environmental and in functional physical terms, delivering social and economic well-being. Assessments are made of the suitability of the site and its surrounding area, identifying implications arising for flood risk, ecology, energy, transport and other subjects mandated as statutory requirements. These tests establish the 'principle of development', confirming the suitability of the site for development. The assessments also provide the information, including preliminary costings, necessary for planning the infrastructure framework. Surveys and projections are also made at this phase of the economic circumstances which will shape market demand and of the social needs to be taken into account in the preparation of the master plan.

During the development of the design, concern is given with how the plan area can best be arranged into development parcels and linked by movement routes and a green network. Attention is focused on establishing the spatial pattern of blocks, routes, spaces and the green scape. Design alternatives require the assessment of the quality of living provided by the design alternatives and the manner of providing public benefits.

The spatial master plan becomes a visual and physical scheme that describes an inter-connected urban environment of complementary land uses, design principles and content. The visual master plan is partnered with quantification of the numbers of housing units, commercial floor space and so on, and the estimates of the development costs and of market prospects. The phasing of the development of infrastructure and site programming is considered. The individual site parcels, consequent on the master plan being approved, will become the subject of detailed design of buildings and the place environment, and will be brought forward when market or other considerations allow.
The phases of analysis and design development are led by a master-planning team. To be effective, the team engages in extensive and intensive consultation with the statutory consultees and the local community during these preparatory phases.

Evaluation is conducted internally by the developer through the master-planning team and externally through the formal consideration of the developer's application for planning approval by the planning authority. The latter will take into account the requirements of the statutory agencies and representations from the local community and wider interests. A master plan is evaluated against two sets of criteria: the developer's investment criteria and the development framework set out in the planning authority's statutory development plan including all mandatory requirements. The investment criteria of cost, return and risk are critical for the developer who must operate within the commercial environment on which they are dependent for loan finance. The planning authority should be mindful of the economic viability of development, and will apply development plan policy when assessing the master plan. The developer must ensure that the master plan complies with the planning policies.

A CSA undertaken by an approved independent assessor in conjunction with the master-planning team may be submitted in support of the planning application. The CSA assesses the performance of the master plan against sustainability standards. The focus is on providing a summative assessment of the predicted performance of the master plan with an emphasis on the quantitative measurement of defined outcome indicators.

Formal approval of the master plan is 'the starting point of a place production process to shape, incorporate change, and reshape the built environment' (Adams and Tiesdell, 2013: p. 74). The tactical value of the 'visioning' master plan is to win planning approval and also investor support for the developer promoting the venture. The approved master plan is a collective agreement of what the various stakeholders expect to see realised (Watson, 2010). It is now appropriate to assess the value of the CSA in informing decision-making in the master-planning process.

\section{The generics of community sustainability assessment}

The necessity to assess the impacts of large-scale developments in order to secure regulatory approval and investment for large-scale projects has driven the production of sustainability assessment tools and performance metrics (AlWaer et al., 2014; Cole and Jose Valdebenito, 2013; Sharifi and Murayama, 2014). The scope of sustainable development has consolidated around the international definitions of sustainable development principles following the Rio Declaration and 
Agenda 21 (Pope et al., 2004: p. 614), emphasising the role of development in delivering healthy and productive living standards but achieving this while simultaneously ensuring the protection of the environment, the conservation and management of natural resources and ensuring inter-generational equity. The motive for conducting an assessment is that when informed by better information a better scheme of development can be framed, the delivery of which results in 'a future that is more viable, durable, pleasant and secure' (Gibson, 2006: p. 172). Sustainability assessment is then an integrative umbrella term that encompasses a wide range of assessment practices that are concerned with the long-term impacts of development.

A CSA is claimed to be a practical and reliable tool for assessing how well a proposed development accords with the principles of sustainable development. CSAs provide for the ex-ante assessment of master plans for medium-/large-scale urban development projects (ex-ante refers to the assessment made prior to the implementation). In the last few decade, CSA systems such as Breaam Communities (UK), Leadership in Energy and Environmental Design (Leed) Neighborhood Development (USA), Comprehensive Assessment System for Built Environment Efficiency (Casbee) Urban Development (Japan), Green Star Communities (Australia), Qatar Sustainability Assessment System (QSAS) Neighbourhood (Qatar), Pearl Community Rating System and Estidama (UAE), among others, have become available (AlWaer et al., 2014; Haapio, 2012; Sharifi and Murayama, 2013, 2014). Notwithstanding that individual CSA systems incorporate features that make them distinctive to the respective parts of the world in which these are used; they share a generic architecture and methodology.

Emulating scientific practice in the manner of its operating model, the CSA method makes use of standardised assessment practices. Indicators translate scientific knowledge into meaningful and manageable units of information, playing the role as 'presentations of measurement to suit particular needs' (Brandon and Lombardi, 2011: p. 74). A wide range of technical standards and techniques of baseline analysis and impact measurement have become established and are used in assessing the performance of urban development. The aim is to ensure that the indicators are 'measurable, comparable, transferable, informative and acceptable for policy choices' (Du Plessis, 2012: p. 12; Finco and Nijkamp, 2001: p. 294).

Consideration in developing the CSA approach has been paid to how the performance of different criteria can be considered in aggregate and how results can be communicated in a format understandable to those not versed with specialist knowledge across all disciplines. A simplified methodology of weighting and scoring the performance of a plan or project against sustainability categories is used. The scoring of the assessment, broadly speaking, comprises two phases; awarding points from each criterion within a topic category. The potential scale of the impact of each criterion is considered against standards when allocating points. Points are awarded based on how much of the performance is above the target or below a benchmark. Those with higher potential of causing impacts are weighted more heavily (Sharifi and Murayama, 2013: p. 8).

A summing of the points achieved against each criterion produces an overall performance figure for each category. The method thus highlights areas of performance shortfall which can be addressed and the aggregated 'scorecard' allows for comparing the sustainability of design options. The function of the performance 'scorecard' is to communicate to a planning authority and other stakeholders as providing a 'balanced' assessment. As such it can be deployed as supporting evidence of serving sustainability objectives in the negotiation of a master plan through the regulatory process.

To date, few local planning authorities require that major development proposals are supported by the availability of a CSA assessment (examples are Bristol City Council and Eastleigh Borough Council). In general, planning authorities continue to specify a set of single-subject assessments tailored to the issues associated with the nature of individual planning application. Currently, a CSA is largely voluntarily commissioned by developers and used by master-planning teams when it is recognised internally that the information provided by the use of such an expert system will be helpful in the design and evaluation of decision-making. There may be reputational benefits from being seen to use robust quality assurance systems, and the importance of 'brand recognition and flagship projects' in the global consultancy market, demonstrating the application of national and international standards and techniques is driving the increased use of CSAs (Cole and Jose Valdebenito, 2013; Spinks, 2015). While a CSA can be applied to a regeneration project, overwhelmingly the use of CSAs has been to provide for the appraisal of the sustainability of planning and design options for the development of new medium- and large-scale neighbourhoods (AlWaer et al., 2014; Sharifi and Murayama, 2013).

In their antecedents the CSA tools can be seen to be 'spin-off tools' from third-party building certification schemes (Sharifi and Murayama, 2013, 2014). These building certification schemes are Breeam (UK), Leed (USA), Sustainable Building Challenge (SBC), Casbee (Japan), Green Star (Australia), QSAS (Qatar), Estidama (UAE) and so on (AlWaer and Kirk, 2012). These tools are strongly aligned with the procedures of quality assurance practice. They use third-party assessors to appraise and rate the scope and performance of master plans in satisfying sustainability standards. Just as the requirements of quality assurance have come to require the internalised 
practice of quality management in design and production processes, the same realisation is increasingly evident in the practice of sustainability assessment. The importance of assessing sustainability during the processes of local context and site appraisal and design generation is increasingly recognised (Mathur et al., 2008).

\section{Breeam Communities 2012}

The interest in this paper is in considering whether the current CSA model provides an adequate approach for assessing the sustainability implications of a large-scale development proposal. The inquiry is made by assessing the suitability of Breeam Communities (2012) in the context of development planning in the UK.

Breeam is the CSA tool developed by BRE Global Limited, a third-party approval body with a long-established reputation for certification in the building and environmental sectors in the UK and internationally. Breeam is intended to assess the potential achievement of the key environmental, social and economic sustainability objectives of large-/medium-scale development projects. The tool is designed to assist in the preparation of development proposals to meet the standards that provide social and economic benefits, while mitigating the environmental impacts of the built environment (Breeam Communities Technical Manual SD202 (BRE, 2012)).

The assessment tool aims to provide 'an accessible, holistic and balanced measure of sustainability impacts'. Central to the tool is a framework of performance standards that cover the social and economic benefits of development and the mitigation of impacts of the built environment. These are claimed to 'use best available science and practice as the basis for quantifying and calibrating cost-effective performance standard for defining sustainability' (Breeam Communities, Technical Manual SD202, Version vii, (BRE, 2012)).

Breeam is framed in line with the understanding of sustainable development, which underpins the UK government's sustainable development strategy. That is, the CSA is organised to assess how well a development proposal will achieve the five guiding principles of the UK sustainable development strategy. Breeam thus fits with the policy framework that guides the UK planning system.

\section{Reviewing a CSA}

Hacking and Guthrie (2008: p. 73) suggest that a sustainability assessment system must be 'comprehensive, strategic and integrated'. The preceding outline of the statutory system established that development decisions are required to be made against knowledge of the implications of the proposed development. Master planning was identified as requiring holding a strategic and long-run perspective; and that appropriate information about development implications had to be forthcoming at timely points during the process of masterplanning in order to integrate with and influence decisionmaking. Our attention turns to examine what these requirements cover.

Comprehensiveness implies an understanding of the implications for sustainability associated with development. The regulatory environment pertaining to sustainability now covers an extensive and growing spectrum of categories, each of which draws on scientific knowledge. Comprehensiveness describes a full coverage. However, the sum of aspects that could be reviewed within the sustainability categories is potentially compendious. What matters is that appropriate weight is given to examine the issues that matter most for producing the overall sustainability outcome. Development projects have to meet mandatory requirements, and each development has uniqueness associated with its time, place and its constituent interests. Accordingly, the balance of issues salient to affecting long-run sustainability has to be viewed, not only in terms of the compliance obligation, but also as relative to what sustainability challenges are presented by the nature of its uniqueness.

Strategic refers to a process of making choices (Friend and Hickling, 2005) in a manner that is selective and judgmental. It requires building the information base about issues, risks and solutions, clarifying interests and objectives, and reaching coordinated decisions. It requires that the process of masterplan preparation is progressed through a sequence of connected decision-making on which the overall sustainability of a development depends.

Different phases of the master-planning process focus on specific problem concerns. The strategic decisions made early in the process will be much concerned with macro-factors of social demographics and need, economic opportunity and demand, and spatial and environmental considerations. Subsequently, attention turns to site level considerations and to how a user-friendly design of the layout, services and facilities is achieved.

A good assessment framework aligns with the phases of decision-making of the master-planning process. To be useful for informing decision-making, the relevant assessment information has to become available at appropriate junctures ('stagegates') during the process of master-planning. This requires considering how well the CSA provides timely information that matters into the strategic decision-making.

Integrated implies bringing together and making whole. The CSA aims to bring disparate information together in order to synthesise an overall judgment on the predicted 
performance of the proposed development. The range of impacts to be assessed is extensive and diverse. Measurement techniques differ. Not all impacts can be measured in quantitative terms.

The requirements of a CSA to be comprehensive, strategic and integrated lead to posing three questions.

Does the CSA provide an adequate coverage of the master-planning process?

- How well are the outputs of CSA aligned with strategic decision-making during the master-planning process?

- How satisfactorily does the CSA provide a basis for integrative assessment?

The review of the adequacy of the CSA approach in relation to these questions now focuses on Breeam.

\section{Does the CSA provide an adequate coverage of the master-planning process?}

There is an inevitable tension between the aspiration to be comprehensive and the necessity to provide a consistent, practical generic tool that is attractive to the development market and to policymakers (Schweber, 2013). Breeam reflects the pragmatic realism that its use much depends on lightening the burden of data collection and analysis. Breeam has used fewer assessment issues, categories and mandatory requirements (around 40 criteria) in comparison with the Breeam 2009 version (BRE, 2009) (around 55 criteria). The tool allocates sustainability issues into five impact categories: governance, social and economic well-being, resources and energy, land use and ecology, and transport and movement. A further category (innovation) is formed to recognise site-wide innovative solutions that deliver benefits not recognised in the individual impact categories. Within each broad category, sub-categories identify specific sustainability issues.

Aiming to provide that the performance of a master plan gives appropriate weight to the issues fundamental to its overall sustainability, Breeam sets 11 mandatory standards as pre-requisites of performance across the five categories to cover the 'fundamental sustainability issues'. These are the planning issues that determine the suitability of the location and site for development and the economic and social case for the content of the proposed development. Although the assessment of many of the issues is very closely linked and impacted on by site selection- this is more about recognising the context than determining the suitability of the location - a subtle difference.

The assessment of urban sustainability requires establishing a framework of sustainability indicators that harness environmental, social and economic dimensions. The benefit of indicators is their ability, when assembled into a collective account, to summarise the complexity of the dynamic environment to a manageable amount of meaningful information (Singh et al., 2009: p. 191). However, sustainability indicators have developed 'incrementally' without a structured framework or consensus on what urban sustainability covers (Alberti, 1996; Bossel, 1998; Deakin, 2009; Deakin et al, 2002; Lombardi and Cooper, 2009; Mitchell, 1997). Many of the indicators in use are contingent on targets set by policymakers (Alberti, 1996; Bossel, 1998: p. 73; Deakin, 2009; Du Plessis, 2012: p. 13; Lombardi and Cooper, 2009; Mitchell, 1997). Policy follows issues that currently affect the community. As such, policy offers a contemporary source of selected indicators. Breeam reflects this approach to indicator selection.

Sustainability indicators arise from values ('we measure what we care about'), and they create values ('we care about what we measure') (Meadows, cited in Singh et al., 2009: p. 191). Breeam adopts and places emphasis on indicators that are quantifiable and able to measure technically the defined criteria relating to economic and social, environmental and building factors.

By its choice of indicators where the use of quantified measures is possible Breeam puts certain issues on the map and, in doing so, may take the spotlight off others. Although the assessment tool has expanded its framework to include social and economic indicators, this moved the assessment into territory where there is greater difficulty to quantify and much less consensus regarding the selection of performance metrics (Cole, 2012: p. 44). In this regard, a number of authors have challenged the adequacy of Breeam with its primarily technical focus and reliance on generic frameworks to contribute to the governance aims of sustainable settlements (Du Plessis and Cole, 2011; Schweber and Haroglu, 2014).

The treatment paid by Breeam to the economic and social aspects of sustainability is present. Economic baseline analysis, social needs analysis and skills gap analysis are part of step 1 baseline focus of the CSA. In step 2 design review of the CSA process, the implications for social and economic wellbeing are identified. A consultation plan and engagement methods are mandatory. It is evident that Breeam aims to raise the good practice standard. However, it largely lets the planning authority and public service providers to set the requirements to be expected of the developers - the local community are also given significant prominence in the framework.

The conceptual bias in Breeam (BRE, 2012) is towards the resources and energy, land use and ecology categories. Breeam distinguishes the relative importance of categories by 'adopt (ing) best available science and practice as the basis for 
quantifying and calibrating a cost-effective standard for defining sustainability' (BRE, 2012: p. vii)). This is carried into the weighting attached to the significance of the various indicator categories. In terms of weightings, 'resources and energy' credits are weighted the most heavily $(21 \cdot 6 \%$, followed by 'social well-being' (17.1\%), 'local economy' (14.8\%), 'transport and movement' (13.8\%), 'land use and ecology' (12.6\%), 'environmental conditions' (10.8\%) and 'governance' $(9 \cdot 3 \%)$. Breeam uses an explicit weighting system derived from a combination of consensus-based weightings and ranking by a panel of experts. The outputs from this exercise are then used to determine the relative value of the categories used in Breeam and their contribution to the overall Breeam score. Category weightings were developed by determining the impact of each category against each of the three pillars of sustainability: social, economic and environmental. The three pillars are equally valued in the manual. Once the category weightings were derived, the individual assessment issues were weighted by prioritising the importance of each assessment issue in terms of its impact on the overall aim of the category. The 'Social and economic wellbeing' category was broken down into three subcategories for weighting purposes. This is to ensure the weightings are based on clearly defined aims. However, different criteria within the indicator categories will interest different stakeholders and weightings should perhaps change from place to place, depending on the strategic national and regional needs - there is a process for this as part of the international process. Weighting issues therefore remain a controversial concern when assessing sustainability. There can be no definite rule to determine customised weighting, which has made the practice vulnerable to ambiguity (Chew and Das, 2008: p. 11).

\section{How well are the outputs of CSA aligned with strategic decision-making during the master-planning process?}

Breeam primarily 'provide(s) a common framework of assessment that is tailored to meet the 'local' context including regulation, climate and sector' (BRE, 2012: p. vii)). It recognises the changes in the UK planning policy, building regulations and development management procedures. It adopts established sustainability indicators linked to the 'core planning principles' in the NPPF (Department for Communities and Local Government, 2012) (Table 1).

Breeam (BRE, 2012) is designed to be used as a method for considering sustainability issues and opportunities in the preparation of a master plan. To this end, Breeam adopts a threestep sequential assessment approach aligned with the critical stages of the master-plan preparation (Table 2).

'Step 1' assesses the proposition that there should be development at this location. The strategic focus is on assessing how the development of the site would impact on the local social and economic circumstances and environment, and, in turn, how the environment and local needs would impact on its
Core planning principles

Empower local people to shape their surroundings

Drive sustainable economic development

Meet housing, business and development needs

High-quality design

Mitigate against and adapt to climate change

Conserve and enhance environment

Reuse land

Promote mixed-use developments

Conserve heritage assets

Make fullest possible use of sustainable transport

Support local strategies to improve health, social and cultural well-being

Table 1. Breeam Communities links to the 'core planning principles' in the NPPF, after building research establishment (BRE, Watford, UK)
Breeam Communities (BRE, 2012)

Governance category
SE 01 - economic impact
SE 17 - training and skills
SE 05 - housing provision
SE 06 - delivery of services, facilities and amenities
GO 03 - design review
Resources and energy category
SE 10 - adapting to climate change
Land use and ecology category
LE 02 - land use
Transport and movement category
GO 01 - consultation plan
SE 14 - local vernacular
Transport and movement category
Social and economic well-being category

Governance category

SE 01 - economic impact

SE 17 - training and skills

SE 05 - housing provision

SE 06 - delivery of services, facilities and amenities

GO 03 - design review

SE - adapting to Climate change

LE 02 - land use

Transport and movement category

GO 01 - consultation plan

Transport and movement category

Social and economic well-being category 
Breeam

Communities

(BRE, 2012)

Step 1: establishing the principle of development

Step 2: determining the layout of the development

Step 3: designing the details
Consultation, innovation, evaluation and determining

\begin{tabular}{cc} 
Breeam (BRE, 2012) & Planning authority \\
\hline $\begin{array}{l}\text { Interim certification: } \\
\text { mandatory criteria }\end{array}$ & $\begin{array}{l}\text { Requirements set by planning authority } \\
\text { covering required consultation and } \\
\text { achieved }\end{array}$
\end{tabular}

Assessment of design against performance criteria, proceed and continue into step 3

Permission in Principle: development framework satisfies planning policies set in local development plan infrastructure, form and ecological systems

Detailing the place: design of individual sites including blocks, spaces, links and landscaping, site transport facilities
Final certification: overall Full planning permission: detailed sustainability rating assessed

\author{
planning application meets \\ requirements of planning policies, \\ regulations, standards and guidance
}

Table 2. Breeam Communities (BRE, 2012) and the

master-planning process

design and development. Sustainability issues of local economic characteristics, demographic trends and service needs, flood risk, energy resource implications and infrastructures requirements at the whole site level are addressed. This step involves critically reviewing the data that supports the planning authority's development plan strategy and making a local analysis to provide a sufficient baseline of knowledge of the conditions and foreseeable trends and predictable changes.

'Step 2' assesses how well the content and layout of place and links affording movement is planned to achieve optimal user benefits and well-being and ensure the protection of local ecology. This assessment matches with the level of information required for the production of the master plan that will become the subject of the application for planning permission in principle. The focus of strategic interest here is in how well the master plan would provide an accessible spatial built environment capable of meeting the everyday requirements of residents.

'Step 3' is concerned with assessing the sustainability that is 'built in' through a more detailed design of buildings and place. The assessment is concerned with establishing how well the designs for local neighbourhoods would meet householders' expectations in providing safe, efficient and attractive residential places (BRE, 2012) is not designed to assess the sustainability of the community to emerge post-development. BRE is understood to be developing a post-construction check. Considering the lengthy build-out implementation of master plans, post-occupancy monitoring will be a welcome addition to good practice. This assessment is required at the point when detailed designs are subsequently prepared for local sites within the master plan and contractors are being engaged, so there is emphasis on good site and procurement practice.

The consultation plan is a mandatory requirement in Breeam 2012. The stakeholders involved in consultation at step 1 (strategic) and step 2 (layout) changes as different sets of expertise and knowledge are called upon. Appropriately, the role of the process of design review is highlighted as central in step 2 . Although Breeam 2012 encourages developers to go beyond statutory requirements, how far public consultation is pursued much depends on what the planning authority expects from the developer's team.

Conducting the sustainability assessment process through the sequence of three steps is intended to provide timely information, enabling constructive dialogue between the evolving master-planning team, the developer, the local planning authority, other statutory consultees and, importantly, members of the existing local communities, local businesses and interest groups. The Breeam 2012 assessment measures the performance of the proposed master plan against sustainability criteria and this assessment will be supporting evidence when formal planning applications are made. However, the achieved performance recorded by the use of sustainability assessment may be manipulated at the margins by the tactic of gaining additional sustainability points to improve the certificated 'scorecard' of performance (giving greater appeal to the master plan) or seeking market appeal through a non-critical enhancement of elements of the plan. 
Moreover, the master-planning team will acknowledge that the financial imperatives of the developer, the local authority and statutory utilities will impinge on the achievement of sustainability. Other assessment tools must be used for evaluating issues of viability and feasibility. Breeam 2012 is not a tool of financial appraisal. However, the standard discounted cash flow financial appraisal fails to cost the longer term 'whole life' risks, costs and benefits of a development for all stakeholders. 'Triple bottom line' assessment (Sridhar, 2011; Vanclay, 2015) is geared towards achieving this long-run appraisal. Such an approach would require the results of a Breeam 2012 (BRE, 2012) appraisal.

\section{How satisfactorily does the CSA provide a basis for integrative assessment?}

It is the development project, not the team members or team as a whole, which is assessed. The developer by adopting to use Breeam 2012 will engage an accredited sustainability assessor to review the information of survey, analysis and mitigation identified during the master-planning process. The assessor does not certify, this is the role of BRE Global, but has the responsibility to meet the compliance requirements for the identified categories and indicators, the technical robustness of analysis and the achievement of sustainability standards. Our interest turns to considering how this assessment is made.

Breeam 2012 claims to be underpinned by the perspective of scientific realism. BRE assume a 'best available technology not entailing excessive cost' approach. The application of science and technical development focuses on the specific levels compartmentalised within the sustainability categories. The basis for the selection of theory, the production of facts and thereafter the predictive interpretation of their implications for long-run sustainability is un-stated in large measure. The diverse scope of the dimensions of sustainability covered by Breeam 2012 entails harnessing the analytical techniques and data interpretations arising from multiple scientific and policy sources that may be weakly connected. The revision of regulations and other standards means that pragmatically there is ongoing change in the technical criteria and in weightings. However, this may create a micro-mentality and solutions to one indicator fail to be adequately taken into account requirements or solutions to another one (Schweber, 2013).

The choice of indicators and the weighting process influences the focus of sustainability considered. What is assessed will determine how design alternatives are considered and selected in decision-making. However, the uncritical use of a prescriptive technical manual for conducting sustainability assessment risks losing sight of the bigger picture. All involved in a sustainability assessment need to reflect on the relevance of the indicators and to satisfy themselves that the right things are being measured (Bond and Morrison-Saunders, 2013: p. 43; Bond et al., 2012, 2013).

BRE Global Ltd have aimed to construct a unifying framework by their framing of Breeam 2012; however, the tool generates a set of specific assessments. Their assembly, as in all CSA tools, is by a simplistic aggregation of credits ascribed by the assessor for the performance of the master plan across the spectrum of sustainability categories. However, the 'balanced scorecard' approach may open opportunities for manipulation to achieve the highest score possible. Considering a range of CSAs, Garde (2009), Sharif and Murayama (2012), and Spinks (2015) identified that some developers engage in a 'hunting points game' as opposed to robust thinking about achieving sustainability.

Breeam 2012 introduces professionals to a range of sustainability-related considerations outside of their expertise. But it also supports the input of many professionals that otherwise may not be engaged with, or engaged with at a stage too late to usefully contribute. This constraint applies to professionals in the private sector as well as those engaged in regulatory and services roles. It is debatable how trans-disciplinary and collaborative some planning teams actually are. Practice is much influenced by what the planning authority is asking for as 'evidence' and whether the developer's own approach to team set-up and project management enables a truly integrated, disciplinary approach. The 'top-down' method and somewhat conservative approach to engagement of the Breeam 2012 approach may fail to stretch sufficiently the aspirations of both regulators and master planners.

\section{Conclusions}

Although from the holistic perspective a sustainable community would be the outcome of a mutually reinforcing balance of social, economic and environmental factors, this vision currently far exceeds the function of the spatial master plan. The job of the latter is to provide a satisfactory development framework that coordinates co-investment by public and private partners in the provision of site servicing infrastructure and subsequently in the construction of a sustainable urban neighbourhood environment. The master plan must satisfy a small but key set of partners who are essential for attracting investor commitment and regulatory approval. It has to be evidenced that the scheme of development complies with regulatory standards; that it is capable of delivering acceptable financial returns for its investors; and that locally relevant social and economic benefits and environmental sustainability can be realised through its implementation.

In this paper, the adequacy of Breeam 2012 as a CSA evaluation tool has been considered through a critical lens, 
requiring that it should provide an assessment that is comprehensive, strategic and integrated. Conclusions can now be drawn from the preceding review of Breeam (2012) against these requirements.

Breeam 2012 has been developed as a means for demonstrating whether a master plan meets regulatory standards. Acknowledging this, the assessment tool covers a relevant scope of sustainability categories and makes use of well-established indicators. Of course, sustainability is a moving target and there is 'no state to be reached' (Gibson et al., 2013). BRE Global Ltd operates on the presumption that sustainability assessment process and practice can be improved. Breeam 2012 does promote good practice and tests the master-planning team to deliver beyond the regulatory minimum.

The preparation of a master plan can be viewed as a temporary complex project with long-term outcomes. In the UK, large-scale spatial development is most frequently developer led. The commissioning of a Breeam 2012 assessment is taken by the developer who also engages and directs the master-plan team. Collaboration with the planning authority and with other statutory bodies and consultation with the local public and other affected stakeholders is required. The preparation of a master plan involves a progressive process of strategic choice. Breeam 2012 can be employed to provide relevant performance information for decision-making at the strategic stage gates of the master-plan process. It can assess the implications of development on environmental and resource factors, and more generally assess the impacts the development would have for meeting local social needs and supporting the local economy. These inform the strategic decisions taken on the principle of development. Subsequently, it can provide information that is relevant for assessing the strategic alternatives of layout and physical form from the viewpoint of their social and economic functionality. Mathur et al. (2008) affirm that sustainability assessment should not be a separate process or a 'snapshot exercise', Breeam 2012 can be seen as providing a stronger framework and input into strategic junctures within the decisionmaking process.

Sustainability assessment is not an aim in itself, instead it should promote and facilitate the quality of decision-making (Devuyst, 2000; Mathur et al., 2008). Strategic choice in the preparation of the master plan involves taking into account regulatory requirements, uncertainties, investment returns and risk, and stakeholder interests and engagement.

However, Breeam 2012 cannot integrate these decision areas but makes no claim to do so. The strength that Breeam 2012 contributes into the strategic decision-making is the knowledge of long-term impacts. Too often, major development decisions with lasting impacts are taken by public and private bodies against short-term considerations. Breeam 2012 provides an assessment method that can assist decision-makers to consider whether in the preparation of a master plan adequate attention is given to 'future-proofing'.

The methodology of Breeam 2012 draws on expert knowledge and the application of analytical techniques. However, there is a quantification bias and limited use of social science practices. The worth of the reported evaluation of performance much depends on the quality of inquiry conducted by the assessor. The unique features of individual master-plan contexts require to be recognised and the third party independent auditor must take a flexible and professionally driven approach in interpreting the appropriate requirements and seeking when necessary confirmation of 'valid' technical alternatives through recorded discussion with BRE technical staff. The assessor has a vital role to play in positively supporting the collation and interpretation of data by the master-planning team, the developer and the planning authority.

The lasting importance of Breeam 2012 may lie in that it can provide a framework for dialogue and mutual comprehension about long-run sustainability between collaborating design and development professionals. What matters is that sustainability assessment becomes the opportunity for learning and influencing the decisions made in master-planning. The CSA assessment requires being a part of formative decision-making rather undertaken as a summative and secondary consideration for the purpose of certification to be used for endorsing or brand purposes. Breeam 2012 scores well on this yardstick. However, a CSA assessment does not mean that the process will automatically produce quality or sustainable places once it becomes operational and changes occur (Bond and Morrison-Saunders, 2013). To this end, a post-occupancy, stakeholder-led evaluation of the success of a Breeam 2012-certificated development will be a welcome evolution.

'A sustainability assessment process is a series of (decision), procedures and documents... but more importantly it is a process and a matrix of relationships' (after Ardron et al., 2008). There is the challenge of making CSA into a more participative process that stimulates developers, planning authorities and design teams to think coherently about sustainable development and increases their awareness of the sustainability measures in their work is required (Berardi, 2011, 2013). Perhaps, CSA governance can be reconsidered by adopting an exploratory learning approach to provide for better dialogue. This would likely involve the stakeholders in the process of master-plan preparation in choosing indicators and a weighting process that communicates to a variety of different actors and disciplines (D'Acci and Lombardi, 2010: p. 21). These actors could together form and share a holistic understanding of the locality and engage in an integrated process of 
defining priorities (Barton et al., 2010: p. 66). The aim has to be to promote a shared understanding of the sustainability issues and there upon proceed to generate solutions that build on revealed knowledge synergies (Barton et al., 2010; Bordass and Leaman, 2013; Du Plessis, 2012: p. 13).

\section{Acknowledgements}

The authors thank Mrs Cary Buchanan from Building Research Establishment (BRE), Mrs Carol Somper from the SoSustainable, and Dr Ian Cooper from the Eclipse Research Consultants, who generously gave their time and knowledge in reading and commenting on this paper.

\section{REFERENCES}

Adams D and Tiesdell S (2013) Shaping Places: Urban Planning, Design and Development. Routledge, London, UK.

Alberti M (1996) Measuring urban sustainability. Environmental Impact Assessment Review 16(4-6): 381-424.

Ardron R, Batty E and Cole I (2008) Devising and Delivering Master-Planning at Neighbourhood Level: Some Lessons from the New Deal for Communities Programme. Department for Communities and Local Government, London, UK.

AlWaer H (2014) Improving contemporary approaches to master planning process. Proceedings of the Institution of Civil Engineers - Journal of Urban Design and Planning 167(1): 24-34, http://dx.doi.org/10.1680/udap.12.00022.

AlWaer $\mathrm{H}$ and Kirk D (2012) Building sustainability assessment methods. Proceedings of the Institution of Civil Engineers Engineering Sustainability 165(4): 241-253, http://dx.doi. org/10.1680/ensu.10.00058.

AIWaer H, Bickerton R and Kirk D (2014) Examining the components required for assessing the sustainability of communities in the UK. Journal of Architectural and Planning Research 31(1): 1-26.

Barton H, Grant M and and Guise R (2010) Shaping Neighbourhoods for Local Health and Global Sustainability, 2nd edn. Taylor and Francis, London, UK.

Barker K (2004) Review of Housing Supply. HM Treasury, London, UK.

Berardi U (2011) Beyond sustainability assessment systems: upgrading topics by enlarging the scale of assessment. International Journal of Sustainable Building Technology and Urban Development 2(4): 276-282.

Berardi U (2013) Sustainability assessment of urban communities through rating systems. Environment, Development and Sustainability 15(6): 1573-1591.

Bond A and Morrison-Saunders A (2013) Challenges in determining the effectiveness of sustainability assessment. In Sustainability Assessment: Pluralism, Practice and
Progress (Bond A, Morrison-Saunders A and Howitt R (eds)). Routledge, Oxon, UK, pp. 37-50.

Bond A, Morrison-Saunders A and Pope J (2012) Sustainability assessment: the state of the art. Impact Assessment and Project Appraisal 30(1): 53-62.

Bond A, Morrison-Saunders A and Howitt R (eds) (2013) Sustainability Assessment: Pluralism, Practice and Progress. Routledge, Oxon, UK.

Bordass B and Leaman A (2013) A new professionalism: remedy or fantasy? Building Research and Information 41(1): $1-7$.

Bossel H (1998) Earth at a Crossroads. Cambridge University Press, Cambridge, UK.

Brandon P and Lombardi P (2011) Evaluating Sustainable Development in the Built Environment. John Wiley \& Sons, London, UK.

BRE (2009) Breeam Communities Technical Manual. BRE Global Limited, Watford, UK. See http://www.breeam.org/ filelibrary/BREEAM\%20Communities/BREEAM_ Communities_Stage_2_Version_1_280211v1.pdf (accessed 21/11/2014).

BRE (2012) Breeam Communities Technical Manual SD202 0:2012. BRE Global Limited, Watford, UK.

Cabe (2011) Creating Successful Masterplans: A Guide for Clients. Cabe, London, UK. See http://webarchive. nationalarchives.gov.uk/20110118095356/http://www.cabe. org.uk/masterplans (accessed 26/05/2015).

Chew MYL and Das S (2008) Building grading systems: a review of the state-of-the-art. Architectural Science Review 51(1): $3-13$.

Cole RJ (2012) Transitioning from green to regenerative design. Building Research and Information 40(1): 39-53.

Cole RJ and Jose Valdebenito M (2013) The importation of building environmental certification systems: international usages of Breeam and Leed. Building Research and Information 41(6): 662-676.

Cowan R (2002) Urban Design Guidance: Urban Design Frameworks, Development Briefs and Master Plans. Thomas Telford Ltd, London, UK.

Cowan R (2008) PAN 83 Planning Advice Note, Master Planning. The Scottish Government, Edinburgh, UK. See http://www.gov.scot/Publications/2008/11/10114526/0 (accessed 26/05/2015).

Cowan R, Adams S and Chapman D (2010) Quality reviewer: Appraising the Design Quality of Development Proposals. Thomas Telford Ltd, London, UK.

D'Acci L and Lombardi P (2010) MuSiC - a new multi-scalar index for evaluating sustainability in cities. In The Second International Conference on Sustainable Architecture and Urban Development (Lehmann S, AlWaer H and Al-Qawasmi J (eds)). The Centre for the Study of Architecture in the Arab Region Publications (CSAAR), Amman, Jordan, vol. 3, pp. 19-34. 
Deakin M (2009) The search for sustainable communities. In Sustainable Urban Development, The Toolkit for Assessment (Vrekeer R, Deakin M and Curwell S (eds)). Routledge, London, UK, vol. 2, pp. 233-247.

Deakin M, Curwell S and Lombardi P (2002) Sustainable urban development: the framework and directory of assessment methods. Journal of Environmental Assessment Policy and Management 4(02): 171-197.

Department for Communities and Local Government (2012) National Planning Policy Framework. Department for Communities and Local Government, London, UK. See https:/www.gov.uk/government/uploads/system/uploads/ attachment_data/file/6077/2116950.pdf (accessed 28/11/ 2014).

Devuyst D (2000) Linking impact assessment and sustainable development at the local level: the introduction of sustainability assessment systems. Sustainable Development 8(2): $67-78$.

Du Plessis C (2012) Towards a regenerative paradigm for the built environment. Building Research and Information 40(1): 7-22.

Du Plessis C and Cole RJ (2011) Motivating change: shifting the paradigm. Building Research and Information 39(5): 436-449.

EC (European Community) (2015) EIA Directive (85/337/EEC). European Commission Publications, Luxembourg. See http://ec.europa.eu/environment/eia/eia-legalcontext.htm (accessed 26/04/2015).

EC (2001) Directive 2001/42/EC of the European Parliament and of the Council. European Commission Publications, Luxembourg. See http://eur-lex.europa.eu/legal-content/ EN/TXT/?uri=CELEX:32001L0042 (accessed 26/04/2015).

Falk N (2011) Masterplanning and infrastructure in new communities in Europe. In Urban Design in the Real Estate Development Process (Tiesdell S and Adams D (eds)). Wiley, London, UK, pp. 34-53.

Finco A and Nijkamp P (2001) Pathways to urban sustainability. Journal of Environmental Policy and Planning 3(4): 289-302.

Friend J and Hickling A (2005) Planning Under Pressure: The Strategic Choice Approach. Elsevier ButterworthHeineman, Oxford, UK.

Garde A (2009) Sustainable by design: insights from US Leed-ND pilot projects. Journal of the American Planning Association 75(4): $424-440$.

Gibson RB (2006) Sustainability assessment: basic components of a practical approach. Impact Assessment and Project Appraisal 24(3): 170-182.

Gibson B, Hassan S and Tansey J (2013) Sustainability Assessment: Criteria and Processes. Routledge, Oxon, UK. Haapio A (2012) Towards sustainable urban communities. Environmental Impact Assessment Review 32(1): 165-169.

Hacking T and Guthrie P (2008) A framework for clarifying the meaning of triple bottom-line, integrated, and sustainability assessment. Environmental Impact Assessment Review 28(2): 73-89.

Highway Act 1980 (1980) Elizabeth II. Chapter 66. Her Majesty's Stationery Office, London, UK. See http://www. legislation.gov.uk/ukpga/1980/66/pdfs/ukpga_19800066_en. pdf (accessed 24/04/2015).

HM Government (2005) Securing the Future: Delivering UK Sustainable Development Strategy. HM Government, London, UK. See http://www.sd-commission.org.uk/ data/files/publications/SecFut_complete.pdf (accessed 26/04/2015).

Holmans A (2013) New estimates of housing demand and need in England, 2011 to 2031. In Town \& Country Planning Tomorrow Series Paper. TCPA and Alan Holmans/ Cambridge Centre for Housing and Planning Research, London, UK, vol. 16, p. 4.

Karol E and Brunner J (2009) Tools for measuring progress towards sustainable neighborhood environments. Sustainability 1(3): 612-627.

Llewelyn-Davies (2007) Urban Design Compendium. English Partnerships, London, UK.

Lombardi P and Cooper I (2009) The challenge of the e-Agora metrics: the social construction of meaningful measurements. International Journal of Sustainable Development 12(2): 210-222.

Mathur VN, Price AD and Austin S (2008) Conceptualizing stakeholder engagement in the context of sustainability and its assessment. Construction Management and Economics 26(6): 601-609.

Mitchell G (1997) Problems and fundamentals of sustainable development indicators. Sustainable Development 4(1): $1-11$.

Office of the Deputy Prime Minister (2005) ODPM Circular 05/2005. Her Majesty's Stationery Office, London, UK.

Patton MQ (1981) Creative Evaluation. Sage publications, Beverly Hills, CA, USA.

Planning Act 2008 (2008) Elizabeth II. Chapter 29 Her Majesty's Stationery Office, London, UK. See http:// www.legislation.gov.uk/ukpga/2008/29/introduction (accessed 26/04/2015).

Planning and Compulsory Purchase Act 2004 (2004). Elizabeth II. Chapter 5. Her Majesty's Stationery Office, London, UK. See http://www.legislation.gov.uk/ukpga/ 2004/5/contents (accessed 28/04/2015).

Pope J, Annandale D and Morrison-Saunders A (2004) Conceptualising sustainability assessment. Environmental Impact Assessment Review 24(6): 595-616.

Schweber $L$ (2013) The effect of Breeam on clients and construction professionals. Building Research and Information 41(2): 1-17.

Schweber L and Haroglu H (2014) Comparing the fit between Breeam assessment and design processes. Building Research and Information 42(3): 300-317. 
Sharifi A and Murayama A (2013) A critical review of seven selected neighborhood sustainability assessment tools. Environmental Impact Assessment Review 38: 73-87.

Sharifi A and Murayama A (2014) Neighborhood sustainability assessment in action: cross-evaluation of three assessment systems and their cases from the US, the UK, and Japan. Building and Environment 72: 243-258.

Singh RK, Murty HR, Gupta SK and Dikshit AK (2009) An overview of sustainability assessment methodologies. Ecological Indicators 9(2): 189-212.

Spinks M (2015) Understanding and actioning BRE environmental assessment method: a socio-technical approach. Local Environment 20(2): 131-148.

Sridhar K (2011) A multi-dimensional criticism of the triple bottom line reporting approach.
International Journal of Business Governance and Ethics 6(1): 49-67.

Town and Country Planning Act 1990 (1990) Elizabeth II. Chapter 8. Her Majesty's Stationery Office, London, UK. See http://www.legislation.gov.uk/ukpga/1990/8/pdfs/ ukpga_19900008_en.pdf (accessed 24/04/2015).

UN (1985) A/RES/42/187. Report of the World Commission on Environment and Development. 96th plenary meeting, 11th December 1987. See http://www.un.org/documents/ga/ res/42/ares42-187.htm (accessed 14/07/2015).

Vanclay F (2015) Changes in the impact assessment 2003-2014: implications for considering achievements, gaps and future directions. Journal of Environmental Assessment Policy and Management 17(01): 1550003.

Watson C (2010) Masterplanning Science and Technology Parks: A BRE Guide. BRE Press, Watford, UK.

\section{HOW CAN YOU CONTRIBUTE?}

To discuss this paper, please email up to 500 words to the editor at journals@ice.org.uk. Your contribution will be forwarded to the author(s) for a reply and, if considered appropriate by the editorial board, it will be published as discussion in a future issue of the journal.

Proceedings journals rely entirely on contributions from the civil engineering profession (and allied disciplines). Information about how to submit your paper online is available at www.icevirtuallibrary.com/page/authors, where you will also find detailed author guidelines. 